\title{
正町 正
}

ボリ[1-(トリメチルシリル)-1-ブロピン] 膜への気体の远過 下村秀樹，中西和樹，小谷 高，合田 道夫, 增田俊夫, 東村敏延, 高分子論文集, 43, No. 11, pp. 747-753 (1986)

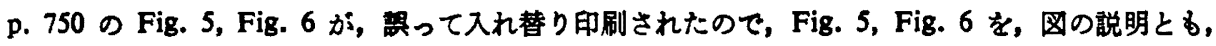
下に示するのに訂正します.
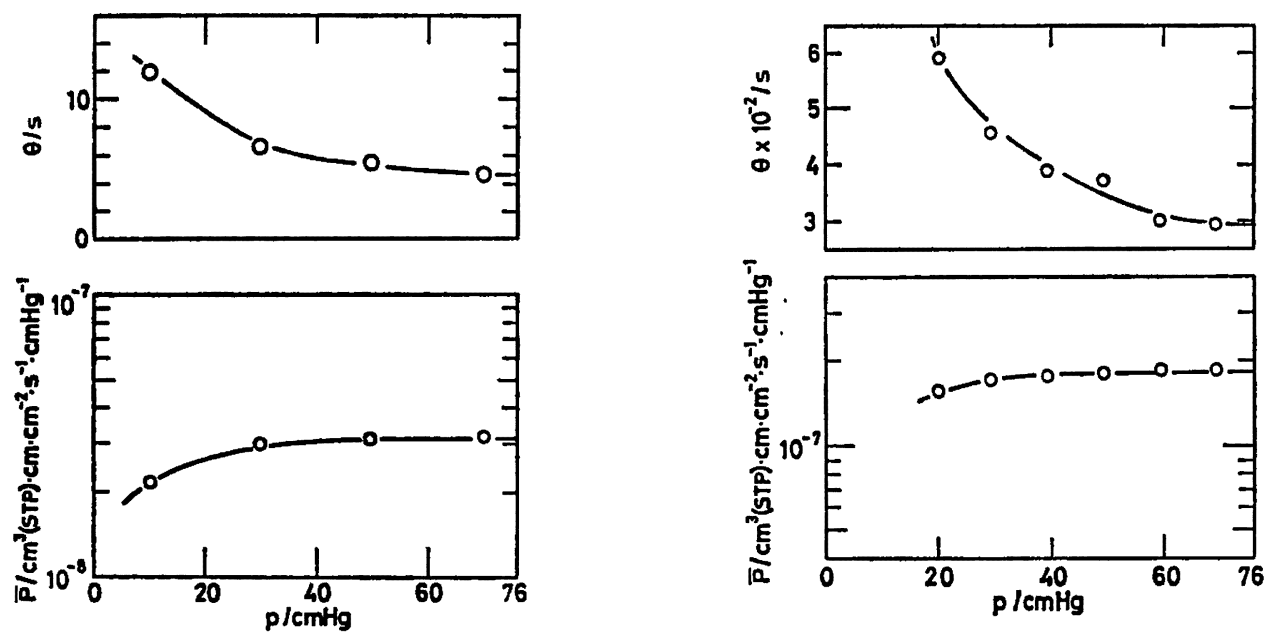

Fig. 5. Pressure dependence of $P$ and $\theta$ for oxygen in P (TMSP) film (No. 1) at $30^{\circ} \mathrm{C}$. 1st series; total time under vaccum: $85-87$ days.

Fig. 6. Pressure dependence of $P$ and $\theta$ for isobutane in $P$ (TMSP) film (No. 2) at $70^{\circ} \mathrm{C}$. 1st series; total time under vaccum: $141-147$ days. 